\title{
ASPEK PENDIDIKAN KARAKTER DALAM PUISI HAMKA
}

\author{
Nani Solihati \\ FKIP Universitas Muhammadiyah Prof. Dr. HAMKA \\ email: nanisolihati@yahoo.co.id
}

\begin{abstract}
Abstrak
Penelitian ini bertujuan mendeskripsikan nilai pendidikan karakter dalam puisi-puisi HAMKA. Metode yang digunakan adalah metode deskriptif kualitatif. Sumber data adalah sebelas puisi karya Hamka dari buku Kenang-kenangan 70 Tahun Buya HAMKA dan KenangKenangan Hidup. Data dikumpulkan dengan membaca secara cermat kandungan makna tiap puisi dan melakukan pencatatan. Analisis data dilakukan dengan teknikdeskriptif kualitatif model Miles dan Huberman, yaitu dengan langkah identifikasi fokus penelitian, reduksi data, analisis dan penyajian data, sertapembuatan inferensi. Hasil penelitian menunjukkan bahwa puisi-puisi karya HAMKA mengandung nilai pendidikan karakter yang meliputi: (1) religiositas, (2) kejujuran, (3) kerja keras, (4) kemandirian, (5) semangat kebangsaan, (6) cinta tanah air, (7) peduli sosial, dan (8) tanggung jawab. Lewat puisipuisinyanya terlihat upaya HAMKA untuk menyampaikan pesan-pesan yang penuh makna tentang pemberian tuntunan kepada pembaca untuk menjadi manusia seutuhnya yang berkarakter dalam dimensi hati, pikiran, raga, serta rasa dan karsa.
\end{abstract}

Kata kunci: pendidikan karakter, puisi, HAMKA

\section{ASPECTS OF CHARACTER EDUCATION IN HAMKA'S POEMS}

\begin{abstract}
This study aims to describe character education values in HAMKA's poems. It used the qualitative descriptive method. The data sources were HAMKA's 11 poems in his books Kenang-kenangan 70 Tahun Buya HAMKA and Kenang-Kenangan Hidup. The data were collected by reading the content and meaning of each poem carefully and recording them. They were analyzed by the qualitative descriptive technique using Miles and Huberman's model consisting of research focus identification, data reduction, data analysis and display, and inference making. The results show that HAMKA's poems contain character education values that include: (1) religiosity, (2) honesty, (3) hard work, (4) autonomy, (5) nationalism spirit, (6) love of the homeland, 7) social care, and (8) responsibility. Through his poems HAMKA tried to convey meaningful messages about the giving of guidance to the reader to become a whole person with characters in the dimensions of heart, mind, body, feeling, and intention.
\end{abstract}

Keywords: character education, poems, HAMKA

\section{PENDAHULUAN}

Kondisi sosial masyarakat Indonesia modern yang cenderung individualis terlihat telah keluar dari budaya Indonesia. Hal itu tidak terlepas dari pengaruh perkembangan teknologi yang begitu pesat dan kurangnya kegiatan-kegiatan kebudayaan yang melibatkan interaksi silaturrahim yang dulu dibangun oleh para pendahulu. Kondisi ini merupakan pertanda berbunyi keras yang memperingatkan kita semua bahwa Indonesia 
kini jauh berbeda dengan Indonesia masa lalu. Kondisi pendidikan Indonesia juga menunjukkan situasi yang tidak jauh berbeda. Kecenderungan perilaku konsumtif, hedonisme, kurang disiplin, dan berbagai sikap buruk lainnya yang dilakukan oleh para pelajar, bukan merupakan sesuatu yang aneh. Hal ini dapat terjadi karena praktik pendidikan yang terlalu berorientasi pada pengembangan kognitif belaka padahal pendidikan bukan hanya persoalan mencerdaskan, tetapi juga membentuk akhlak atau kepribadian yang baik. Hal ini ditegaskan oleh Wuryandani dkk (2016:208), yaitu bahwa siswa di sekolah tidak cukup hanya dikembangkan aspek akademiknya saja,tetapi juga aspek moral dan spiritual.

Pendidikan dipandang gagal mengembangkan akhlak peserta didik. Hal itu disinyalir karena penerapan porsi pembelajaran sastra lebih banyak merupakan pembelajaran yang mentransfer pengetahuan (transfer of knowledge), bukan pembelajaran yang mentransfer nilai (transfer of values). Padahal, Suryaman (2010:114) menyatakan bahwa pembelajaran sastra dapat memberikan pencerahan intelektual dan mental.

Selain itu, karya sastra memiliki fungsi sebagai sarana pendidikan (Sehandi, 2014: 15-20). Pendidikan yang direpresentasikan lewat karya sastra bukan pendidikan yang sifatnya kognitif yang berupa pengertian-pengertian, ciri-ciri, atau apa pun yang membuat manusia berpikir keras, melainkan pendidikan yang merekontruksikan kehidupan sehingga penuh dengan pengetahuan empiris. Hal inilah yang ditegaskan Nurgiyantoro (2004:207) bahwa karya sastra berbicara tentang kehidupan sehingga memberikan pemahaman yang lebih baik tentang kehidupan yang berupa eksplorasi berbagai bentuk kehidupan. Dengan begitu, sastra sebagai sarana pendidikan, mampu menyampaikan nilai, pesan, cita-cita, dan perasaan yang terkandung di dalam batinnya.
Pengalaman batin tersebut merupakan sarana pendidikan bagi masyarakat penikmat karya sastra tersebut (Sehandi, 2014:17-18). Pendidikan tidak lagi hanya direpresentasikan sebagai sebuah proses pemerolehan pengetahuan dari lembaga pendidikan, tetapi lebih diejawantahkan sebagai upaya menumbuhkembangkan berbagai sikap, nilai, pesan, serta citacita luhur bagi peserta didik. Hal ini senada dengan pendapat Sukardjo dan Komarudin (2009:9) bahwa pendidikan adalah kumpulan dari semua proses yang memungkinkan seseorang mampu mengembangkan seluruh kemampuan (potensi) yang dimilikinya, sikap-sikap, dan bentuk-bentuk perilaku yang bernilai positif dalam masyarakatnya.

Praktik pendidikan yang bertujuan menanamkan nilai-nilai positif serta mengembangkan sikap dan perilaku peserta didik dikenal dengan Pendidikan Karakter. Pendidikan karakter adalah proses pemberian tuntunan kepada peserta didik untuk menjadi manusia seutuhnya yang berkarakter dalam dimensi hati, pikiran, raga, serta rasa dan karsa (Samani dan Hariyanto, 2011:45).Kemendiknas (sekarang Kemendikbud, 2011:8) menetapkan18 nilai-nilai yang dikembangkan dalam pembelajaran di sekolah. Ke-18 nilai tersebut adalah religius, jujur, toleransi, disiplin, kerja keras, kreatif, mandiri, demokratis, rasa ingin tahu, semangat kebangsaan, cinta tanah air, menghargai prestasi, bersahabat/komunikatif, cinta damai, peduli lingkungan, peduli sosial, dan tanggung jawab.

Salah satu upaya yang dapat dilakukan menanam dan memupuk nilai pendidikan karakter kepada peserta didik adalah dengan penyebarluasan karya sastra baik tulis maupun lisan. Karya sastra tulis merupakan simbol kemajuan literasi dapat dijadikan sebagai jawaban untuk memperbaiki kondisi sosial masyarakat yang cenderung pragmatis dan hedonis. Berkaitan dengan hal tersebut, pengkajian 
nilai-nilai yang terdapat dalam karya sastra tulis merupakan langkah penting untuk penyebarluasannya. HAMKA, sebagai salah satu sastrawan besar semasa Pujangga Baru, menghasilkankarya sastra yang penting dan berpengaruh bagi bahasa Indonesia sehingga perlu untuk dikaji secara seksama. Selain dikenal sebagai ulama, HAMKA juga produktif melahirkan karya sastra. Novelnya bahkan menjadi bacaan yang populer di kalangan masyarakat, seperti novel $D i$ Bawah Lindungan Kabah dan Tenggelamnya Kapal Vanderwijck. Keberadaan dua novel legendaris tersebut, menempatkan HAMKA sebagai sastrawan Indonesia yang cukup berpengaruh terhadap genre sastra religius di Indonesia.

Selain menulis novel, HAMKA juga menulis cerita pendek dan puisi. Dibandingkan dengan novelnya, kedua genre karyanya ini memang tidak terlalu familiar. Meski demikian, tidak jauh berbeda dengankarya novelnya yang menyampaikan berbagai pesan dan nilai luhur yang menyentuh dan mendidik, cerita pendek dan karya puisi HAMKA pun mengandung nilai yang demikian.

Khusus untuk puisi-puisinya, HAMKA memiliki gaya kepenyairan yang unik dan khas. Ia tidak terlalu bermain dengan kata-kata yang indah penuh gaya bahasa. Sebaliknya, ia lebih memilih untuk menggunakan kata-kata yang padat, tegas, jelas, dan ekspresif sehingga mudah dimaknai oleh para pembaca. Cara yang dilakukannya sah-sah saja. Sujarwoko (2015:239) menyatakan bahwa puisi merupakan karya yang ditulis dengan padat, ringkas, dan ekspresif. Walaupun demikian, bukan berarti puisi HAMKA tidak indah dan kurang artistik. Ada aspek lain yang menjadi keunggulannya, seperti dikemukakan oleh Kosasih (2008:3) bahwa keindahan puisi tidak hanya pada penggunaan majas, melainkan juga penggunaan rima dan irama. Brooke (1970:5) menyatakan bahwa bahasa yang digunakan oleh pengarang dapat menuntun ke pemahaman yang lebih baik terhadap makna yang digunakan pengarang. Dalam konteks puisipuisi HAMKA, keindahan yang dibangunnya merupakan keindahan dengan mengedepankan rima yang baik. Dengan bentuk puisi semacam itu, gagasan kepenyairan HAMKA mudah dipahami dan dimaknai karena ia menggunakan ekspresi konkret dari kekuatan imajinasi dan pikirannya.

Penelitian ini difokuskan pada pengkajian puisi-puisi HAMKA untuk mengungkap nilai-nilai pendidikan karakter yang terkandung. Pengkajian dilakukan dengan asumsi dasar bahwa HAMKA merupakan sosok yang lengkap. Ia tidak hanya berjuang menanamkan nilai-nilai dalam bentuk tulis, tetapi juga dalam bentuk lisan. Ia sosok pendakwah yang ulung. Pengajar yang disegani muridnya. Apa yang diajarkannya adalah apa yang dilakukannya. Ia tidak menggurui, tetapi orang yang berdiri di depan cermin, sementara pembaca atau pendengarnya merupakan cermin yang berusaha memantulkan apa yang diajarkannya. Selain itu, penelitian ini sebagai upaya pembacaan etis terhadap karya sastra, mengingat relasi antara sastra dan etika sebenarnya memiliki sejarah panjang yang dapat dilihat namun kini semakin memudar (Fawaid, 2013:131).

\section{METODE}

Penelitian ini menggunakan pendekatan tekstual yang mengkaji kandungan unsur tertentu dalam wacana puisi. Penelitian menggunakan pendekatan kualitatif yang bersifat deskriptif karena cara kerja dan data yang diperoleh berupa data verbal serta diolah dengan logika kualitatif. Subjek penelitian adalah puisi karya HAMKA diperoleh melalui penelusuran cukup berliku dan memerlukan waktu karena selama hidupnya HAMKA tidak pernah membukukan puisi-puisinya dalam bentuk buku kumpulan puisi. 
Hasil penelusuran menemukan dua buku, yaitu Kenang-Kenangan Hidup (1952)dan Kenang-kenangan 70 Tahun Buya HAMKA (1979) yang di dalamanya juga memuat puisi. Puisiyang ditemukan dan kemudian diteliti sebanyak sebelas buah, yaitu yang berjudul: (1) "Kepada Soekarno-Hatta”, (2) "Wolter Robert Monginsidi (dan 40.000 Syuhada di Sulawesi)",(3) "Kepada Saudaraku M. Natsir", (4) "Sesudah Naskah Renville", (5) "Roda Pedati", (6) "Taubat", (7) "Nikmat Hidup", (8) "Hati Sanubari", (9) "Hanya Hati", (10) "Menekur Saja", dan (11) "Mengapa Baru Sekarang".

Data dikumpulakan lewat kerja pembacaan dan pencermatan berulang-ulang (intrarater) tiap puisi untuk memperoleh pemahaman tentang kandungan makna pendidikan karakter dan kemudian diikuti kerja pencatatan. Untuk memastikan ketepatan makna yang telah diperoleh, dilakukan diskusi dengan sejawat (interrater). Analisis data dilakukan dengan mengikuti analisis model Miles dan $\mathrm{Hu}-$ berman (1992) dengan langkah: (1) identifikasi objek penelitian, (2) reduksi data, (3) penyajian data, dan (4) pembuatan inferensi yang berupa pemaknaan dan pembuatan kesimpulan. Langkah analisis data ditunjukkan pada Gambar 1.

\section{HASIL DAN PEMBAHASAN \\ Hasil}

Hasil penelitian menunjukkan bahwa nilai pendidikan karakter pada puisi-puisi HAMKA meliputi hal-hal: (1) religius, (2) jujur, (3) kerja keras, (4) mandiri, (5) semangat kebangsaan, (6) cinta tanah air, (7) peduli sosial, dan (8) tanggung jawab. Distribusi nilai-nilai tersebut dapat dilihat pada Tabel 1.

Temuan unsur pendidikan karakter merata pada berbagai puisi terutama aspek religius dan kejujuran. Ada keragaman kandungan unsur pendidikan karakter pada tiap puisi walau dengan intensitas berbeda, bahkan ada dua buah puisi yang tidak secara jelas menyampaikannya.

\section{Pembahasan}

Hasil pengkajianmenunjukkan bahwa puisi-puisi HAMKA memiliki nilai-nilai pendidikan karakter yang kuat. Hal ini terjadi karena kesadaraan akan pentingnya pendidikan karakter tampaknya sudah mendarah daging dalam pandangan kepenyairan HAMKA. Di antara

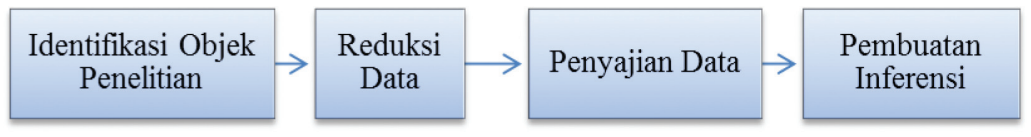

Gambar 1. Analisis Data Kualitatif diadaptasi dari Miles dan Huberman

Tabel 1. Hasil Analis Nilai Pendidikan Karakter Puisi HAMKA

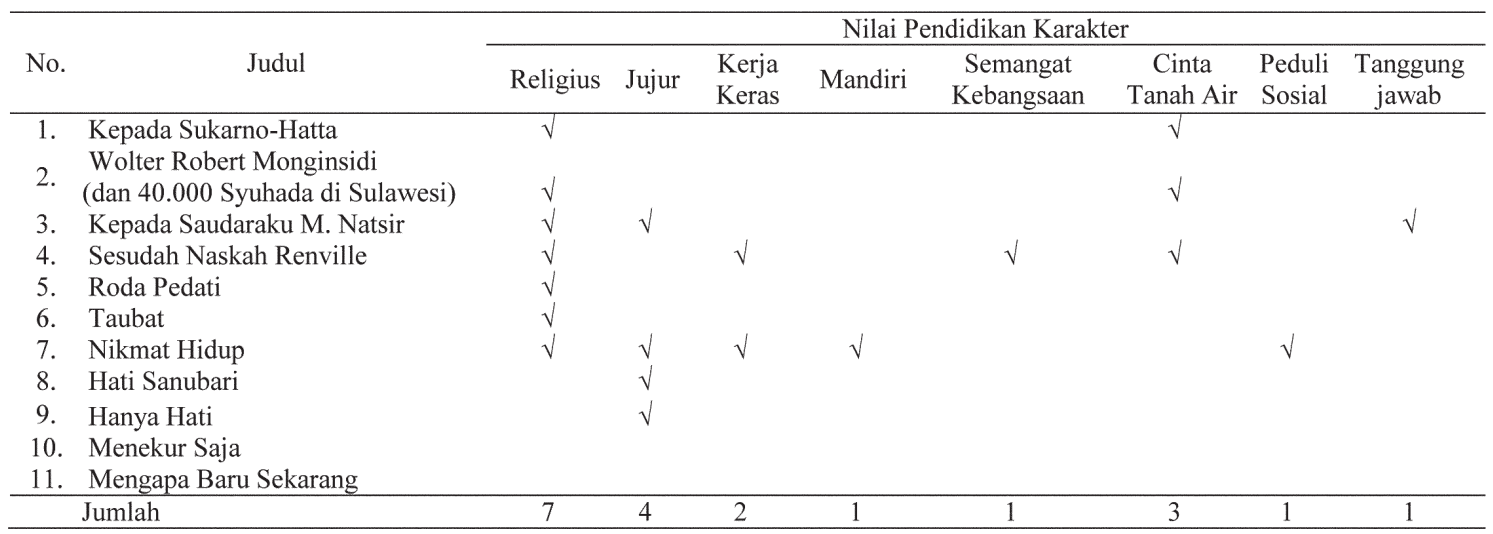


nilai-nilai tersebut adalah karakter cinta tanah air yang direfleksikannya melalui puisi ode, seperti tampak pada puisi yang berjudul"Kepada Sukarno-Hatta".

Dalam puisi tersebut, HAMKA memberikan puja-puji kepada dua sosok yang sangat berjasa dalam menyatukan berbagai perbedaan yang ada di Indonesia sehingga bangsa ini menjadi negara kesatuan. Tidak tanggung-tanggung pujaan tersebut disuguhkan dengan cara membandingkan usaha keduanya dengan usaha para Nabi, yaitu Musa, Isa, dan Muhammad. //Teringatku Musa di Jabal Tursina/Melihat cahaya di malam gulita Teringatku Isa di tasik Galelia/Pemukat menjadi hawari perkasa/Teringatku Muhammad di Jabal Qubis/Faham yang sesat tersapu habis//. Tak sampai di situ, pujaan juga dilakukan dengan menyebut mereka berdua sebagai calon penerus Gajah Mada dan Demang Lebar Daun. Tuan berdua berjiwa satul Seorang lanjutan Patih Gajah Mada/Seorang lanjutan Demang Lebar Daun//.

Dalam puisi ini juga berisikan harapan HAMKA akan kejayaan Indonesia di tangan mereka sebagaimana pernah diraih kerajaan Sriwijaya dan Majapahit sehingga disebut oleh HAMKA di akhir bait ketiga puisi tersebut sebagai suatu hal yang dimaksud dengan tercabut sudah batang terendam. Pada bait selanjutnya, HAMKA menyinggung betapa jasa mempersatukan perbedaan tersebut sangat luar biasa sulitnya, ia menyebut dengan simbol puting beliung yang menggoyang pohon beringin, namun sebaliknya, menurut HAMKA kedua tokoh tersebut justru semakin kokoh, dengan baris puisi /Gelora menambah kokoh berdiri/. Di akhir puisi ini, HAMKA menyebut //Selamat istirahat di istana Gambir/Mengenangkan betapa darah tertumpah// yang memiliki makna bahwa mereka telah mengemban amanah menjadi Presiden dan Wakil Presiden pertama setelah banyak pengorbanan yang mereka lakukan. Berdasarkan penjelasan tersebut dapat ditangkap bahwa puisi ini merupa- kan puisi sanjungan kepada para tokoh yang berjasa dalam membangun negeri, dalam hal ini Soekarno dan Hatta. Oleh karena itu, di sisi lain sebetulnya puisi ini menggambarkan pendidikan karakter cinta tanah air. Bagaimana cara HAMKA mencintai tanah airnya dipantulkan dalam bentuk memberikan ode terhadap Soekarno dan Hatta.

Dalam puisi "Wolter Robert Monginsidi (dan 40.000 Syuhada di Sulawesi)", HAMKA memberikan sanjungan kepada Wolter Robert Monginsidi serta para pejuang yang meninggal dalam usaha merebut kemerdekaan di Sulawesi. Dalam bait-bait puisi ini, bentuk nilai pendidikan karakternya tidak hanya cinta tanah air, namun juga religius yang dalam persepsi HAMKA menjadi fondasi elementer dalam membangun rasa cinta tanah air.

Bilamana dibaca sekilas, puisi ini mengesankan puisi tentang cinta tanah air, bagaimana orang-orang yang berani membela tanah airnya telah mengkerdilkan pikirannya dari maut. Namun sebaliknya, kecintaan tanah air tersebut terwujud berlandaskan atas sifat dan keyakinan religius. Hal inilah yang kemudian membentuk anggapan bahwa maut sebagai jalan menuju ke tempat bahagia, yaitu Menuju suatu tempat baqa. Di tempat itu, digambarkan HAMKA, tidak ada perilaku buruk, penuh bidadari, dan diliputi kedamaian. //Di sanalah hilang hasad dan dengki/Kelaliman dan aniaya/Dan bidadari melagukan lagu-lagu pujaan/Dan Israfil meniupkan serunai Sangka-Kala/Dan kedamaian meliputi ujud semestal/. Hanya dengan karakter religius hal ini dimungkinkan, karena keyakinan bahwa merebut kemerdekaan merupakan jalan menuju Allah (jihad fi sabilillah). Hal ini ditegaskan oleh Sujarwoko (2015: 242) bahwa maut sekaligus juga merupakan kabar gembira, maut sebagai hadiah. Maut merupakan jembatan yang mempertemukan antara diri dengan Tuhan dalam wujud yang sebenarnya. Yang dikira manusia mati itu 
sebenarnya dia masih hidup dan bersuka ria dalam keridoan-Nya.

Bait selanjutnya, HAMKA menyebut Monginsidi memimpin jalannya pertempuran yang membawa mereka kepada kematian. Perjalanan kematian yang penuh dengan keyakinan. Keyakinan yang selanjutnya mendatangkan persepsi bahwa memperjuangkan tanah air merupakan jalan syuhada yang telah ditempuh oleh para pendahulu, //Di sana telah menunggu nenek moyang kita/Yang telah lebih dahulu pergi dari kital Air Anggur, bejana emas beralaskan dalam perak/Telah tersedia penghilang haus dahagamu/Nur Ilahi dan kebesaran Nabi-nabi/Memancarkan sinar maha terang dan abadi/Dan orang-orang suci memakai jubah putih bersih//.

Bahkan keyakinan tersebut, terus dibawa HAMKA sampai pada bait ketiga. HAMKA bahkan mengimajinasikan Tuhan tersenyum sebagai tanda ridha atas perjuangan Monginsidi. //Dan dari atas langit tinggi tujuh tingkat/Menekur senyum melihat alam yang fana/Tempat "Raja Dunia" melakukan megah kuasanya/Insan terpedayal/. Selanjutnya, pada bait ke empat pun demikian, bahwa kematian Monginsidi telah membawanya dekat arasy Tuhan dan menasehati ibunda Monginsidi untuk merelakan putranya yang telah kembali Kedalam haribaan Duli. HAMKA bahkan berkeyakinan bahwa hal tersebut sebagai ...permulaan hidupmu sejati... hal ini merujuk pada Surat Al-Imron ayat 169-170, "Janganlah kamu mengira bahwa orangorang yang gugur di jalan Allah itu mati; bahkan mereka itu hidup di sisi Tuhannya dengan mendapat rezki. Mereka dalam keadaan gembira disebabkan karunia Allah yang diberikan kepada mereka, dan mereka bergirang hati terhadap orangorang yang masih tinggal dibelakang yang belum menyusul mereka, bahwa tidak ada kekhawatiran terhadap mereka dan tidak (pula) mereka bersedih hati. "Berdasarkan penjabaran tersebut maka nilai pendidikan karakter yang terdapat dalam puisi tersebut meliputi cinta tanah air dan religius.

Puisi ode lainnya yang syarat nilai pendidikan karakter berupa cinta tanah air dan religius terdapat pula pada puisi berjudul "Kepada Saudaraku M. Nasir". Selain nilai religius dan cinta tanah air, tinjauan lebih mendalam, sebenarnya puisi tersebut mengandung nilai pendidikan karakter lainnya, yaitu kejujuran. Hal tersebut diungkapkan dalam bait pertama puisi tersebut, //Meskipun bersilang keris di leher/Berkilat pedang di hadapan matamul Namun yang benar kau sebut juga benar/l. Pernyataan tersebut menunjukkan bagaimana HAMKA memandang M. Nasir sebagai orang yang sangat jujur. Kejujuran yang dipancarkannya merupakan kejujuran sebagaimana disebut oleh Suparmi dan Nursa'ban (2012:106)sebagai suatu yang dilandasi oleh nilai-nilai religius dan nilai-nilai etika yang berlaku secara umum.

Bait selanjutnya, masih menyanjung M. Nasir sebagai orang jujur yang mampu meninggikan cita Muhammad. Dalam perspektif Islam, Nabi Muhammad mencita-citakan suatu negara yang baldatun thoyibatun wararabbun ghaffur. Negara seperti itu tidak akan berdiri dengan kokoh jika dipenuhi dengan kemunafikan. Oleh karena itu, HAMKA berpesan kepada M. Nasir, //Bongkar apinya hingga ketemu/ Hidangkan di atas persada nusall. Dengan kata lain, baris tersebut menuntut Nasir untuk membuka semua sifat-sifat yang menghancurkan negara, dalam hal ini sikap-sikap bernegara yang buruk seperti koruspsi, kolusi, dan nepotisme. Dalam penggalan puisi ini menegaskan suatu pandangan bagaimana mencintai tanah air dengan menjaga sikap bernegara yang baik, selain itu juga harus tetap berfondasi pada agama. Fondasi itulah yang kemudian menjadi dasar HAMKA melanjutkan pada bait ketiga, //Jibril berdiri di sebelah kananmu/Mikail berdiri di sebelah kiri/Lindungan Ilahi memberimu tenaga//. Namun 
sejatinya, dua baris akhir pada bait ini merupakan jembatan penting yang menghubungkan gagasan dibait selanjutnya, //Suka dan duka kita hadapi/Suaramu wahai Nasir, suara kaummu//. Hal ini dikarenakan pada baris tersebut menunjukkan keberpihakkan HAMKA terhadap Nasir, bahkan HAMKA menegaskan bahwa keberpihakan semacam itu, tidak hanya dilakukan oleh HAMKA, namun seluruh rakyat. Dua baris ini menunjukkan suatu getaran yang merefleksikan semangat kebangsaan.

Dengan semangat tersebut, bait selanjutnya menjadi jauh lebih menggebugebu bahkan terkesan menantang Nasir untuk melakukan gerakan-gerakan yang lain, /Ke mana lagi Nasir, ke mana kita lagi/ demikian repetisi tersebut disampaikan sebagai suatu kesungguhan bahwa untuk membentuk negara yang damai, dibutuhkan tanggung jawab bersama. Bukan tanggung jawab pribadi. Bukankah Soekarno membutuhkan sepuluh pemuda? Maka, repetisi tersebut dilengkapi dengan pernyataan suatu tekad yang kuat yang didasari oleh keimanan kepada Tuhan, // Ini berjuta kawan sefaham/Hidup dan mati bersama-sama/Untuk menuntut ridha Ilahi//. Tidak sampai disitu, HAMKA sebagai aku,masuk dalam lirik puisi tersebut, menegaskan kembali keberpihakan kepada M. Nasir dengan bahasa yang lugas, //Dan akupun masukkan!/Dalam daftarmu...//

Representasi cinta tanah air HAMKA masih dapat dibaca dalam puisi "Sesudah Naskah Renville". Puisi ini sedikit berbeda dengan puisi lainnya. Struktur puisinya menyusun pola pantun dengan irama ab-ab serta berisi sampiran dan isi. Rima yang ketat tersebut tidak menghambat pesan yang hendak disampaikan HAMKA. Semua pesan tersebut seperti menyiratkan bagaimana perspektif kecintaan HAMKA pada tanah airnya.

Bait pertama puisinya menunjukkan bahwa perjanjian Renville merupakan sebuah usaha atas upaya merebut ke- merdekaan, //Hasil didapat kadar usahal Tidak lebih tidaklah kurang/Aduk hati tanyai Jiwa/Jangan menyesal kepada orang//. Sebagai sampiran, dua baris pertama menekankan karakter kerja keras, bahwa hubungan kausal antara hasil dan usaha tidak akan terbantahkan. Berbeda dengan pantun pada umumnya, antara sampiran dan isi tidak memiliki hubungan. Dalam puisi HAMKA ini berlaku sebaliknya, isi dalam pantun itu memiliki hubungan resiprokal, artinya jika dikaitkan dengan dua baris sebelumnya, maka dapat ditarik benang merahnya. Dalam bait tersebut, maka hasil dari perjanjian Renville tersebut hendaknya tak disesali, namun sebaliknya perlu direnungkan. Artinya, HAMKA memandang bahwa perjanjian tersebut dirasa belumlah maksimal, belum maksimal karena dipandang merugikan dan tidak memuaskan banyak pihak. Dalam konteks ini HAMKA menjadi seorang yang arif dan tak muluk-muluk, karena ia mengetahui dan mengalami sendiri. Ia memang seorang pejuang, bahkan ketua Fron Pertahanan Nasional dan Barisan Pengawas Negeri dan Kota.

Dalam bait kedua, seraya memberi nasihat, HAMKA menyampaikan bahwa perjanjian tersebut mungkin saja akan berhasil, namun bukan tanpa kemungkinan juga untuk gagal, maka dalam bait kedua ia menulis sajaknya dengan kata-kata, // Kalau berhembus angin selatan/Jangan lekas riang gembira/Kalau bergoncang tali bubutan/Jangan lekas berputus asa. Dalam kenyataannya perjanjian ini, menghasilkan kesepakatan antara Belanda dan Indonesia tentang batas wilayah Indonesia yang sangat kecil, hanya meliputi tiga wilayah, yaitu Jawa Tengah, Yogyakarta, dan Sumatera. Setelah perjanjian itu, HAMKA juga mengingatkan bahwa untuk mewujudkan cita-cita kemerdekaan memanglah sangat sulit, ia menyimbolkannya dengan harus melewati bukit. Namun jangan putus asa, tetapi tetap berusaha meski hal itu sangat sulit, /Di tengah sawang jangan 
bermenung/Lanjutkan juga betapapun sulit//. Salah satu upaya yang harus tetap membara adalah memelihara keyakinan bahwa Tuhan akan membantu Indonesia untuk merdeka. //Selama iman nyala di dada/Ranah tujuan tidakkan hilang/Tuhan Allah tetap Ada/Tanah airku tetap menang//.

Di akhir puisi ini, berisi bait yang menunjukkan semangat kerja keras dengan mengorbankan banyak hal. Bahwa sekali memperjuangkan kemerdekaan maka tak akan terjajah, namun konsekuensi dari perjuangan itu, adalah sulit berjumpa dengan banyak orang-orang yang terkasihi. Ya, karena usaha untuk kemerdekaan harus meninggalkan mereka. oleh karena itu, //Bertambah banyak sulit berjumpa/Nilai merdeka bertambah tinggi//. Dengan demikian, puisi "Sesudah Naskah Renville" ini memuat banyak nilai pendidikan karakter, selain kerja keras dalam merebut kemerdekaan, juga ada persoalan keimanan yang menjadi dasar, rasa cinta tanah air yang menggelorakan semangat perjuangan, dan semangat kebangsaan yang rela meninggalkan orang-orang tercinta.

Puisi karya Hamka yang berjudul "Roda Pedati" tidak lagi membicarakan tentang ke-Indonesia-an, namun kemanusiaan secara universal yang syarat dengan nuansa religius. Berdasarkan hal tersebut, kereligiusan sepertinya menjadi alam pikiran dan suasana batin HAMKA. Sebagaimana disebut Simatupang (2014:30) bahwa pada dasarnya puisi merupakan manifestasi seluruh alam pikiran dan suasana batin seseorang.

Nilai religius puisi ini terlihat pada keyakinan terhadap kehendak Tuhan yakni pada baris pertama bait kedua yang berbunyi //Demikian kehendak Tuhan Rabbul Izzati//. Pada dasarnya, kehidupan manusia memang naik-turun, kadang berada dalam kondisi yang baik, dan sebaliknya. Melalui simbol roda pedati ini, HAMKA menegaskan bahwa siklus tersebut merupakan sunnatullah (kelazi- man), bahwa manusia adakalanya ia turun dan ia naik, silih berganti. Dalam konteks Islam, keyakinan bahwa Tuhan Maha Berkehendak merupakan Sifat Wajib bagi Allah yang harus diyakini oleh setiap pemeluknya, yakni al-iraadah. Sifat maha berkehendak diterangkan dalam $\mathrm{Al}$ quran, surat Al baqarah, ayat 117: "Allah Pencipta langit dan bumi, dan bila Dia berkehendak (untuk menciptakan) sesuatu, maka (cukuplah) Dia hanya mengatakan kepadanya: 'Jadilah.' Lalu jadilah ia."Keyakinan merupakan bagian penting dari nilai religius. Hal ini ditegaskan oleh Salleh (2012:1) bahwa nilai religius mencirikan suatu kepercayaan kepada Tuhan yang ditandai dengan kesalehan dan semangat keagamaan, semakin tinggi semangat keagamaan, maka semakin kuat keyakinannya pada Allah.

Tak jauh berbeda dengan puisi Roda Pedati, puisi berjudul Taubat juga berisi nilai religius. Dalam perspektif yang berbeda, HAMKA menggambarkan suatu kesadaran keagamaan yang luhur, bahwa dalam ketersesatan jalan hidup, pada akhirnya manusia akan menemukan Tuhannya. Dalam puisinya ini, HAMKA menggambarkan dirinya sebagai sosok yang penuh dosa dan memohon ampun atas dosa-dosa tersebut. Dengan melihat latar belakang sosiologis HAMKA yang seorang ulama, bait pertama tersebut seperti suatu yang aneh jika diungkapkan seorang ulama. Namun, sebagaimana yang dicontohkan oleh Nabi Muhammad yang meski telah dijamin akan masuk surga, Beliau tetap memohon ampun. Dalam konteks tersebut, maka HAMKA menyadari bahwa dirinya merupakan manusia biasa, hanya setitik debu yang hina.

Bait berikutnya merupakan pengakuan bahwa dirinya memang tak lepas dari dosa dengan menyebut bahwa sepanjang hidup telah terlena oleh nafsu dunia fatamorgana, sehingga //mungkinkah kan mengelupas dari tubuh/kotoran-kotoran yang telah mendarah daging menjadi satu/l. Selan- 
jutnya, meski tahu bahwa segala dosa tak akan begitu saja hilang dari tubuh, namun aku lirik dalam puisi ini terus berusaha untuk berdoa agar diterima taubatnya. //berilah yang terbaik/kami yakin ENGKAU MAHA segalanyalkan terima taubat kamil sebelum nyawa terlepas dari raga//. Berdasarkan penjabaran di atas, maka dapat disimpulkan bahwa puisi ini syarat akan nilai religius. Keyakinan bahwa segala sesuatu dapat diampuni Tuhan menjadi titik poin bagaimana HAMKA mengajarkan bahwa Taubat merupakan kuasa Tuhan.

Puisi selanjutnya ialah puisi "Nikmat Hidup".Puisi yang sangat panjang ini berisi kontemplasi kehidupan HAMKA. Dalam puisi tersebut, HAMKA menceriterakan bagaimana perubahan yang dialaminya dan sikap sosial apa yang ditunjukkannya di tengah masyarakat yang majemuk, seraya memberi pesan yang sangat kompleks untuk direnungi.

Pada bait pertama puisi "Nikmat Hidup", merupakan refleksi kehidupan HAMKA, bahwa //Setelah diri bertambah besar/di tempat kecil tak muat lagi, ISetelah harga bertambah tinggi/orang pun segan datang menawar//. Dalam bait ini HAMKA merasa terasing dengan lingkungannya, dengan keilmuan dan kemasyhurannya sebagai seorang ulama dan penulis, ia merasa sudah tak muat lagi. Kata tak muat ini syarat akan simbol sosiologis HAMKA, ia tentu bukan menolak berada di tempat kecil, namun tempat kecilnya yang justru merasa terlalu besar menerima sosok HAMKA. Karenanya, lingkungan masyarakatnya pun merasa segan, bahkan untuk sekedar menawarkan dirinya. Padahal, HAMKA ingin tetap membumi, berada di tengah lingkungannya untuk mensyiarkan Islam. Tampak bahwa HAMKA berupaya menunjukkan sikap kepedulian sosialnya. Namun, ia merasa sikap lingkungan kecilnya tersebut diakibatkan oleh adanya kawan yang culas. Karena keculasan orang itu, ia merasai bagai terpencil.
Bait selanjutnya, seraya menyindir orang culas, ia menyebut bahwa lebih baik kehilangan harta dan benda, asal tak kehilangan harga diri, Walaupun musnah harta dan benda/harga diri janganlah jatuh. Menurutnya, harta benda dapat dicari dengan kerja yang baru, //Binaan pertama walaupun runtuh/kerja yang baru mulailah pula/l. Bait ketiga ini menunjukkan sikap untuk berlaku jujur dengan tidak menghancurkan harga diri, selain itu juga menyuntikkan semangat untuk tetap mempertahankan etoskerjakeras.

Di bait keempat, dengan menjaga budi pekerti atau kejujuran disebut HAMKA akan membuat seseorang tak akan pernah menganggur. Ia bahkan dapat mengkhidmati hidup denganjalan yang seolah-olah disediakan begitu saja bagi orang-orang yang jujur. Seperti tergambar pada bait berikut ini, //Pahlawan budi tak pernah nganggur/khidmat hidup sambung bersambung,/Kadang turun kadang membumbung/ sampai istirahat di liangkubur//.

Selain kejujuran, pesan pendidikan karakter lainnya yang disampaikan HAMKA pada puisinya ini adalah kemandirian. Melalui bait kelimanya, ia menegaskan meskipun susah luar biasa, tetapi janganlah sampai mengemis, //Tahan haus tahanlah lapar/bertemu sulit hendaklah tenang/ Memohon-mohon jadikan pantang/dari mengemis biar terkapar//.

Selanjutnya pada bait keenam, HAMKA memberikan nilai pendidikan karakter kembali,berupa nilai religius. Ia menyebut bahwa manusia sebaiknya tak meminta pertimbangan kepada manusia. Sebaliknya, dengan bertanya kepada Tuhan dan hati, maka kita memiliki ketetapan dalam suatu jawaban. //Hanya dua tempat bertanya/pertama Tuhan kedua hati/Dari mulai hidup sampai pun mati/timbangan insan tidaklah samall.

Nasihat selanjutnya dalam puisi ini adalah untuk bekerja keras. Kerja keras perlu dilakukan untuk meraih cita-cita, namun perlu disadari bahwa hasil kerja 
keras seseorang akan dikenang ketika yang bersangkutan telah tiada. Artinya, orang baru mengenal kita setelah kita dikubur, dan HAMKA menamsilkannya dengan bait//Baru orang tahu siapa diri/ setelah tidur di kubur kelam//.

Bait berikutnya, menunjukkan bagaimana HAMKA berupaya mengingatkan manusia sebagai makhluk religius memiliki tujuan hidup, yaitu tujuan manusia diciptakan ke muka bumi ini semata untuk beribadah kepada Allah, sehingga meski banyak halangan menghadang, HAMKA menasehati diri untuk terus berjuang hingga ajal menjelang, // Sebelum ajal, janganlah mati/keredhaan Allah, itulah tuju/l.

Kesadaran diri atas penciptaan tersebut, kemudian melahirkan pemaknaan konsepsi dasar bahwa setiap tubuh merupakan tempat bagi malaikat dan setan, jika mengikuti arahan malaikat maka kita akan mendapat pujian, sebaliknya jika mengikuti ajakan setan, maka kita akan mendapat celaan. Sesungguhnya hidup merupakan ujian, HAMKA melukiskannya dengan //Selama nampak tubuh jasmani/ gelanggang malaikat bersama setan,/Ada pujian ada celaan/lulus ujian siapa berani,//

Melalui bait//Jika hartamu sudah tak adal belumlah engkau bernama rugi,/Jika berani tak ada lagi/separuh kekayaan porak poranda,// HAMKA memberikan nasihat mengenai bagaimana pentingnya keberanian. Bagaimana seseorang mampu mengambil konsekuensi dari setiap langkah yang dilakukannya. Berani tidaknya membuat keputusan menentukan kesuksesannya.

Jika keberanian dalam bait sebelumnya identik dengan kekayaan, maka HAMKA berpandangan bahwa semua yang dimiliki manusia akan musnah jika martabat diri telah jatuh, seperti tercermin dalam bait berikut, //Musnah segala apa yang adaljikalau jatuh martabat diri,/Wajah pun muram hilanglah seri/ratapan batin dosa namanya//. Dalam bait ini, HAMKA menyampaikan bahwa hakikat manusia adalah mempertahankan martabat dirinya karena sejatinya yang dicari manusia sebenarnya adalah eksistensinya sebagai manusia. Manusia yang mampu menjaga martabat dirinya adalah manusia yang bertanggung jawab atas kehidupannya. Oleh karena itu, bait ini mengajarkan pembaca tentang bagaimana melaksanakan tanggung jawab sebagai manusia.

Bait selanjutnya, HAMKA menyampaikan pesan puitis mengenai kejujuran. //Jikalau dasar budimu culas//, jelasnya dalam baris pertama pada bait kedua belas ini, /tidaklah berubah kerana pangkat/. Artinya, jikalau seseorang memiliki sifat tak jujur, maka ia akan bertindak tidak jujur selamanya, bahkan ketika ia telah mendapatkan kedudukan sekalipun, bahkan HAMKA mensinyalirakan bertambah parah dan terlihat jelas keculasannya seiring kenaikan jabatannya itu, //Bertambah tinggi jejang di tingkat/perangai asal bertambah jelas//. Pernyataan ini dapat dijadikan refleksi kebangsaan saat ini, perilaku korupsi tak lepas dari sistem pemerolehan kekuasaan yang buruk.

Dalam pengimplementasian tindakan jujur, menurut HAMKA, sangat sulit. Karenanya, ia menasihatkan agar bila berkedudukan sebagai penentu kebijakan sebaiknya bertindak tegas bak palu, yang berani memberantas kemungkaran dengan habis-habisan, //Tatkala engkau menjadi palu/beranilah memukul habis-habisan//. Sebaliknya, jika berlaku sebagai bawahan, maka tahanlah segala sesuatu yang menghambat perilaku jujur tersebut dengan sekuat tenaga: //Tiba giliran jadi landasan/ tahanlah pukulan biar bertalu/l.

Sebagai manifestasi dari filosofi palu dan landasan tersebut, HAMKA pun menanggapi nyinyir nasihat yang diterimanya, sebagaimana berbunyi pada bait kelima belas: //Ada nasihat saya terimal menyatakan fikiran baik berhenti,/sebablah banyak orang membenci/supaya engkau aman sentosal/. HAMKA menjawab pada bait berikutnya dengan sangat tegas bahwa // 
Menahan fikiran aku tak mungkin/menumpul kalam aku tak kuasa,/Merdeka berfikir gagah perkasa/berani menyebut yang aku yakin. Bahkan ia lebih menerima celaan maupun makian, sebab disebutnya sebagai hiasan hidup di alam maya. Ini menunjukkan keteladanan yang berusaha disampaikan oleh HAMKA, bahwa ia akan berbuat jujur meskipun mendapatkan cacian. Dalam perjalanan hidupnya, tak jarang HAMKA sangat tegas dalam menyampaikan pikiran meskipun ia harus bersilang pikiran dengan para penguasa.

Puisi berikutnya berjudul "Hati Sanubari". Puisi yang terdiri dari dua bait ini menunjukkan sikap HAMKA yang lebih memilih sikap jujur untuk merawat hati sanubarinya. Berdasarkan puisi tersebut, dapat dibaca bagaimana HAMKA berupaya menanamkan sikap jujur yang tak ternilai harganya bahkan secara satir memberikan sebuah pertanyaan yang menghujam batin pembaca: Adakah rasa hati sanubari itu bisa dijual? Melalui puisi-nya ini, HAMKA bahkan siap dicaci maki, dibenci, dihina, namun HAMKA membutuhkan kesempatan untuk mendemonstrasikan kejujurannya, Biarkanlah saya menyebut apa yang terasa. Dengan begitu, ia mempersilahkan siapapun yang bertentangan dengan suara hatinya, untuk menghinanya, walaupun dengan lembut HAMKA menuliskan dalam baitnya sebagai .../tuan bebas memberi saya namaldengan apa yang tuan sukail. Artinya, penghinaan sehina-hinanya telah siap diterima HAM$\mathrm{KA}$, karena ia merupakan pribadi yang //... pemberi maaf,/dan perangai saya adalah mudah, tidak sulit.//

Tak jauh berbeda dengan puisi sebelumnya yang menekankan kejujuran, puisi berjudul Hanya Hati ini memuat pendidikan karakter yang serupa. Namun, dalam puisi ini, sikap jujur tersebut tidak lagi berhadapan dengan bohong, namun, sesuatu yang seringkali membuat seseorang berbuat bohong, yaitu kemiskinan. HAMKA berupaya menekankan bahwa untuk jujur tak perlu menjadi kaya terlebih dahulu, justru kekayaan terbesar adalah hati. Puisi "Hanya Hati" menghadapkan pembaca pada riwayat Aku Lirik yang penuh kesulitan dan kesengsaraan hidup lantaran kemiskinan yang dialaminya, mulai dari gaji yang kecil, honor menulis buku yang tak diketahui jumlahnya, yang pada akhirnya sulit untuk membelikan permadani, tas atom, kereta kepada sosok yang dicintainya yang disebut Dik. Namun yang menarik dalam puisi ini, ironi yang sengaja ditonjolkan, yaitu korupsi. Dalam bait kedua puisi ini, HAMKA menyebut bahwa Korupsi aku tak mahir. Oleh karena itu, sangatlah jelas bahwa nilai pendidikan karakter dalam puisi ini adalah perihal jujur yang sangat sulit jika diterapkan dalam segala ketercekikan hidup.

Puisi berikutnya merupakan puisi yang mendeskripsikan apa yang dilihat HAMKA perihal orang yang sedang melukis (bait pertama) dan lalu lalang yang berada di sekitarnya, khususnya orang asing bertubuh jangkung yang hendak dituliskan di dalam puisinya (bait kedua). Judulnya Menekur Saja. Puisi ini tak menberikan nilai pendidikan karakter yang kuat. Karenanya, nilai dalam puisi ini tak dapat masuk dalam delapan belas kategori nilai pendidikan karakter. Dalam puisi ini, Hamka lebih banyak menggunakan istilah kedaerahan. Cara demikian sering disebut sebagai penyimpangan bahasa puisi yang berbentuk penyimpangan dialek (Leech, 1969: 42-51), misalnya kata menekur, rancak, santung, dan sanjai. Oleh karena itu, puisi ini kental sekali unsur kedaerahannya.

Puisi selanjutnya berjudul "Mengapa Baru Sekarang", masih dengan bahasa Makasar yang kental, HAMKA menggambarkan tentang sosok yang dicintainya. Puisi ini tidak memiliki nilai pendidikan karakter yang kuat karena hanya menceritakan perasaan Aku Lirik kepada seorang perempuan (Upik) Ketek yang memberi- 
kan harapan kehidupan cinta. Aku Lirik justru ragu menerima senyuman yang diberikan Upik.

\section{SIMPULAN}

Paparan di atas menunjukkan bahwa puisi-puisi karya HAMKA memiliki nilai pendidikan karakter yang kuat, walaupun tidak semua delapan belas nilai pendidikan karakter terkandung di dalamnya. Dari delapan belas nilai pendidikan karakter yang ada, hanya delapan nilai pendidikan karakter yang terdapat di dalam puisi-puisi karya HAMKA, meliputi: (1) religius, (2) jujur, (3) kerja keras, (4) mandiri, (5) semangat kebangsaan, (6) cinta tanah air, (7) peduli sosial, dan (8) tanggung jawab.

Dari delapan karakter tersebut, intensitas yang paling tinggi terdapat pada karakter religius yang termuat dalam tujuh puisi karya HAMKA. Sementara itu, puisi yang paling banyak memuat nilai pendidikan karakter adalah puisi "Sesudah Naskah Renville" yang memiliki empat nilai karakter di dalam satu puisi yang terdiri dari religius, kerja keras, semangat kebangsaan, dan cinta tanah air.

Dari kesebelas puisinya, terlihat upaya HAMKA untuk menyampaikan pesan-pesan yang penuh makna tentang pendidikan karakter berupa proses pemberian tuntunan kepada pembaca untuk menjadi manusia seutuhnya yang berkarakter dalam dimensi hati, pikiran, raga, serta rasa dan karsa.

\section{UCAPAN TERIMA KASIH}

Terimakasih kepada Dekan FKIP UHAMKA yang telah memberi izin dan kepercayaan untuk melaksanakan penelitian dengan judul" Nilai Pendidikan Karakter dalam Puisi-Puisi Karya HAMKA". Terimakasih disampaikan kepada Pusat Kajian Buya HAMKA Universitas Muhammadiyah Prof. Dr. HAMKA Jakarta yang telah berkenan membantu memberi informasi berkaitan dengan puisi-puisi karya HAMKA. Terimakasih dihaturkan kepada Tim editor Jurnal $\mathrm{Li}$ tera yang telah bersedia menyelia naskah artikel ini sehingga naskah menjadi lebih baik, dan semua pihak yang membantu proses pemuatan naskah ini.

\section{DAFTAR PUSTAKA}

Brooke, R.L. 1970. The Language of Dickens. London: Andre Deutsch Limited.

Fawaid, Ahmad. 2013. "Perjumpaan Etis dengan Wajah yang-Lain: Membaca Karya Sastra dengan "Etika" Levinasian".Jurnal Poetika, I (2), 131.

Hamka, 1952. Kenang-Kenangan Hidup. Jakarta: DE UNIE.

Kementerian Pendidikan Nasional. 2011. Panduan Pelaksanaan Pendidikan Karakter. Jakarta: Kementerian Pendidikan Nasional.

Kosasih, E. 2008.ApresiasiSastra Indonesia. Jakarta: PT Perca.

Leech, Geoffrey N. 1969. A Linguistic Guide to English Poetry. New York: Longman.

Miles dan Huberman. 1992. Analisis Data Kualitatif: Buku Sumber tentang Metodemetode Baru. Jakarta: UIP.

Natsir, M. 1977. Kenang-kenangan 70 tahun Buya HAMKA. Jakarta: Yayasan Nurul Islam Jakarta.

Nurgiyantoro, Burhan. 2004. "Kontribusi Sastra Anak dalam Pembentukan Kepribadian Anak".Cakrawala Pendidikan, XXIII (2), 207.

Salleh, Muhammad Syukri. 2012. "Religiosity in Development: A Theoretical Construct of an Islamic-Based Development". International Journal of Humanities and Social Science, 2 (14),1.

Samani, Muchlas dan Hariyanto M.S. 2011. Konsep dan Model Pendidikan Karakter. Bandung: Remaja Rosdakarya.

Sehandi, Yohanes. 2014. Mengenal 25 TeoriSastra. Yogyakarta: Ombak.

Simatupang, Iwan. 2014. Kebebasan Pengarang dan Masalah Tanah Air. Jakarta: Kompas. 
Sujarwoko. 2015. “Citraan Sufistik Maut dan Islam dalam Puisi Indonesia". Litera, 14 (2), 239-249.

Sukardjo, M. dan Ukim Komarudin. 2009. Landasan Pendidikan. Jakarta: Rajawali.

Suparmi dan M. Nursa'ban. 2012. “Implementasi Nilai-nilai Kejujuran dan Tanggung Jawab dalam Perkuliahan di Jurusan Pendidikan Geografi UNY". Socia, 11 (1), 106.
Suryaman, Maman. 2010. “Pendidikan Karakter Melalui Pembelajaran Sastra." Cakrawala Pendidikan, XXIX, 114.

Wuryandari, Wuri. 2016. "Implementasi Pendidikan Karakter Kemandirian di Muhammadiyah Boarding School." Cakrawala Pendidikan, XXXV (3), hlm. 208-216. 